\title{
Comparative Study between Membrane Bioreactor MBR and Rotating Biological Contactors RBC for Greywater Treatment
}

\author{
Amr M. Abdelkader
}

\begin{abstract}
Greywater is the major part of water consumption in houses. Greywater should be treated to complying with the specifications for several purposes such as toilet flush, landscaping irrigation, and agriculture. The treatment efficiency of both MBR and RBC systems was investigated by using a verified mathematical model. The simulation program GPS-X (version 6.0) was used to simulate both MBR and RBC systems. The simulation model for biological treatment for both MBR and RBC systems is based on Activated Sludge Model 1 (ASM1). The experimental data for model calibration and verification for the MBR system were taken from experimental work done at Tubitak, Marmara Research Center, Turkey ATASOY. As well as the RBC proposed model was verified also by using RBC experimental results for a pilot plant according to BABAN. The RBC pilot plant consists of three units, The first is the RBC unit, the second unit is the settling tank and the last unit is the disinfection tank. The results of the MBR plant showed that the removal efficiencies of the greywater were: 95\% for COD; $95 \%$ for BOD5; $96 \%$ for TKN; $92 \%$ for $\mathrm{NH4+}$ and $99 \%$ for TSS. Whereas, the results of the RBC show that, The BOD efficiency removal was ranged between about 93.0 to 96.0 \%, and for the total SS removal was ranged between 84.0 to 95.0 \%. The MBR system provides complete nitrification and suspended solid removal. The RBC system provides less nitrification process and suspended solid removal. The effluent of the rotating biological contactors units for the greywater could be reused after filtration and disinfection with minimal cost of operation. The effluent of the membrane bioreactor unit needs only disinfection before reuse.
\end{abstract}

Index Terms-Membrane bioreactor, rotating biological contactors, greywater treatment, mathematical models, wastewater reuse.

\section{INTRODUCTION}

The polluted wastewater collecting from washing basins, showers, bathtubs, and washing machines is defined as greywater. The economical treatment choices are required to reuse the treated effluent on site. The greywater might be used for many purposes like cleaning water, toilet flushing, and landscape irrigation [1]. Many different greywater treatment plants are in operation, but a comparative review of experiences and results is still lacking [2], [3]. The strong regional and seasonal fluctuations in the quality of the produced greywater at its source make it difficult to create a binding universal treatment pattern as the best available

Manuscript received March 19, 2020; revised December 12, 2020.

Amr M. Abdelkader is with the College of Engineering, University of Business and Technology UBT, Jeddah, Saudi Arabia. He is also with the Sanitary Engineering Department, Faculty of Engineering, Alexandria University, Egypt (e-mail: amr_abdel_kader@yahoo.com). technique [4], [5].

Many treatment options could be used including, Filtration, sedimentation as physical treatment, whereas Rotating Biological Contactors and Sequencing Batch Reactor as a biological treatment process [6], [7]. The membrane bioreactors (MBR) have been utilized as an onsite compact treatment unit. The main advantages of MBRs are to get a good quality of the treated effluent with very less bacteriologic organisms. Also, the membrane system has a high resistance to organic shock loads. The following table can be summarized the advantages and disadvantages of both MBR and RBC systems [8], [9].

\begin{tabular}{|c|c|c|}
\hline Technology & Advantages & Disadvantages \\
\hline $\mathrm{RBC}$ & $\begin{array}{l}\text { - Low operational cost } \\
\text { - Short hydraulic retention } \\
\text { time } \\
\text { - Capable of handling a } \\
\text { variation inflows } \\
\text { - Good process control }\end{array}$ & $\begin{array}{l}\text { - The requirement for covering } \\
\text { RBC units. } \\
\text { - Shaft bearings and } \\
\text { mechanical drive units require } \\
\text { frequent maintenance }\end{array}$ \\
\hline MBR & $\begin{array}{l}\text { - Good effluent quality with } \\
\text { high hygienic standards } \\
\text { - Reduced reactor volume } \\
\text { and footprint } \\
\text { - Reduced net sludge } \\
\text { production }\end{array}$ & $\begin{array}{l}\text { - Complex and costly } \\
\text { pre-treatment of the incoming } \\
\text { wastewater } \\
\text { - Membrane integrity (failure } \\
\text { detection, lifetime) }\end{array}$ \\
\hline
\end{tabular}

The evaluation of both MBR and RBC systems for greywater treatment was done by using a simulation model developed for both systems based on the IWA Activated Sludge Model 1. The modular program used in this study is GPS-X which is a modular, multi-purpose modeling environment for the simulation of municipal and industrial wastewater treatment plants. GPS-X uses an advanced graphical user interface to facilitate dynamic modeling and simulation. GPS-X is also using the most recent advances in process modeling, simulation technology, graphics, and a host of productivity tools that simplify model construction, simulation, and interpretation of results.

The GPS-X program was used in the simulation process. Model verification was done by using the experimental results of two pilot plants. Once the model was validating, the model was used in different scenarios to evaluate the performance of the two treatment processes.

\section{MATERIALS AND MethodS}

\section{A. Experimental Pilot Plant}

1) MBR pilot plant system 
The model calibration and verification for the MBR system were done based on taken experimental work done at Marmara Research Center [10]. Fig. 1 shows the schematic for the MBR experimental pilot plant. The summary of the operational parameters is shown in Table II.

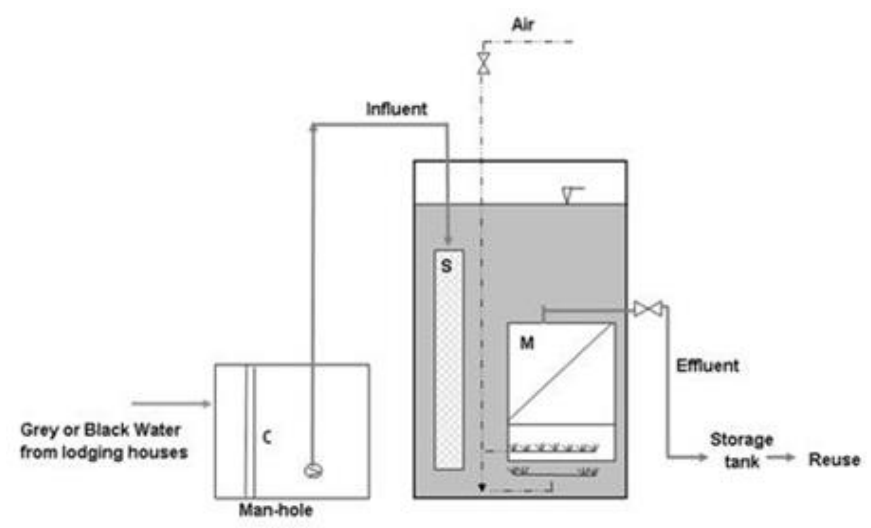

Fig. 1. Membrane bioreactor pilot plant.

TABLE II: MBR PLANT OPERATION CONDITIONS

\begin{tabular}{cc}
\hline \hline Parameter & Greywater \\
\hline Volume & $600 \mathrm{~L}$ \\
Time of operation & $50 \mathrm{~d}$ \\
Influent discharge & $800 \mathrm{~L} \mathrm{~d}^{-1}$ \\
Pore size & $0.4 \mu \mathrm{m}$ \\
Membrane area & $5 \mathrm{~m}^{2}$ \\
Flux & $26-36 \mathrm{~L} \mathrm{~m}^{-2} \mathrm{~h}^{-1}$ \\
HRT & $18 \mathrm{~h}$ \\
Cycle number & $8 \mathrm{~d}^{-1}$ \\
Time of aeration per cycle & $33 \mathrm{~min}^{-1}$ \\
MLSS & $1500 \mathrm{mg} \mathrm{L}^{-1}$ \\
Organic loading & $0.3 \mathrm{~kg} \mathrm{COD} \mathrm{m}^{-3} \mathrm{~d}^{-1}$ \\
\hline \hline
\end{tabular}

\section{2) RBC pilot plant}

After segregation of grey and black water from residential Buildings, Greywater was fed for the rotating biological contactors pilot plant. The greywater has collected the kitchen of the residential buildings. Fig. 2 shows the RBC pilot plant. The treated greywater from the RBC system has been disinfected by using the UV treatment process [11].

The operational conditions for the RBC system will be as follows:

- Coarse screen pore opening $=10 \mathrm{~mm}$.

- Fine screen pore opening $=3 \mathrm{~mm}$.

- The number of RBC discs $=36$, the total surface area of the discs $=16.2 \mathrm{~m}^{2}$.

- Period of RBC plant operation=10 months.

- Influent discharge $=400 \mathrm{l} / \mathrm{d}$.

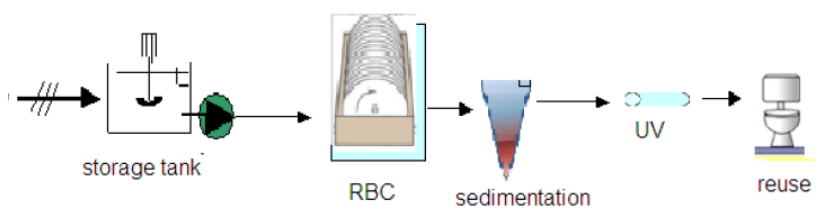

Fig. 2. Rotating Biological Contactor pilot plant.

The activated sludge was used to the rotating biological contactors unit to accelerate the growth of the microorganisms on the discs in the startup period. The sludge was taken from the membrane bioreactor unit which operated with greywater as influent wastewater. The related parameters to the biofilm growth $\left(\mathrm{BOD}_{5}, \mathrm{TKN}, \mathrm{TSS}\right.$, Turbidity, and Total coliform) were measured to confirm that the characteristics of treated effluent satisfy the international reuse regulations. Also, $\mathrm{NH}_{4}{ }^{+}, \mathrm{NO}_{3}{ }^{-}$and Total Phosphorus were measured to control the treatment process.

According to guidelines for wastewater reuse in the EPA standards (especially for landscape irrigation, urban reuses, and toilet flushing), the $\mathrm{BOD}_{5}$ concentration and TSS should be less than 10, 5 ppm respectively. Also, the fecal coliform should not be detected in the sample 100 cubic $\mathrm{cm}$, and $\mathrm{pH}$ should be within the range of 6-9. Whereas, for WHO guidelines the treated greywater reuses have higher allowable values for the same parameters. Hence, the guidelines for the EPA were mainly taken in this study to assist the compliance of the treated effluent for the greywater. The influent greywater concentrations for the rotating biological contactors unit was ranged from a high, medium, and low concentrations to assist the performance of the RBC system.

\section{B. Operation Conditions and Model Configuration}

\section{1) MBR model configuration}

The MBR plant model consisted of two units, the first one is the aeration basin and the other one is the membrane unit for the physical separation of the treated effluent from the aeration tank. The layout of the MBR plant model is shown in Fig. 3. The MBR model was known as the submerged MBR system.

\section{Simulation model and kinetic parameters}

The MBR model includes two main parts: a kinetic module that simulates the biological reactions in the system, and a transport module throw the membrane which represents the physical system modeled to separate the treated effluent from the activated sludge. The MBR kinetic module is based on the ASM1 model. The model has 19 stoichiometric and kinetic parameters. Fractionation of raw grey water and black water to its components, as required by the kinetic module, was performed based on the findings of Dixon et al. [12]: soluble biodegradable COD $45 \%$, particulate biodegradable COD $31 \%$, soluble non-biodegradable COD $15 \%$ and particulate non-biodegradable COD 9\%. Default values for calibration of the MBR model as kinetic parameters were used as initial values for dynamic calibration. The GPS-X program (ver. 6.0) was used as simulation software for the MBR model. Fig. 3 shows the layout for the mathematical model for the MBR system.

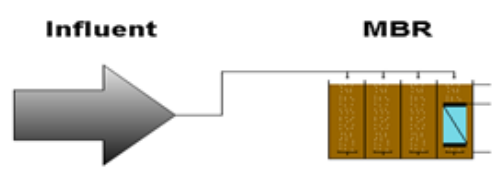

Fig. 3. MBR plant model.

\section{2) RBC model configuration and operation conditions}

The RBC model was used to investigate the greywater treatment capability and performance for the RBC. The GPS-X program was used to simulate the RBC system. Fig. 4 shows the layout for the mathematical model for the RBC system. The RBC proposed treatment plant was composed of three units, the first one was the rotating biological contactors unit, the second was the settling tank and the last one was a 
disinfection unit. The model was optimized for the biological kinetic parameters for the proposed unit. Three concentrations were used as influent greywater to run the proposed rotating biological contactor system. High, medium, and low greywater concentrations were used in different scenarios to run the RBC model.

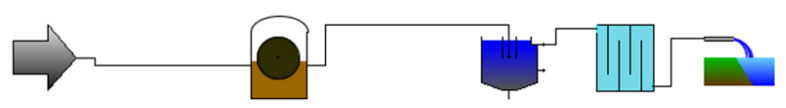

Fig. 4. RBC Model General layout.

Greywater concentrations with wide ranges were used within the experimental work. High, medium, and low greywater concentrations to run the rotating biological contactors model. The experimental results were used to calibrate and validate the model.

\section{Rotating biological contactors pilot plant operation conditions:}

- Influent greywater discharge $=400 \mathrm{l} / \mathrm{d}$.

- $\mathrm{RBC}$ unit volume $=0.2 \mathrm{~m}^{3}$.

- Area of the RBC disks $=16.2 \mathrm{~m}^{2}$.

- $\mathrm{MLSS}=2800 \mathrm{mg} / \mathrm{l}$.

- The submerged ratio of the discs $=40 \%$.

- Settler surface area $=0.5 \mathrm{~m}^{2}$.

- The volume of the Disinfection unit $=301$.

- Chlorination dose $=1.0 \mathrm{mg} / \mathrm{l}$.

\section{Influent Wastewater}

The Influent characteristics for the greywater for both MBR and RBC plant models were shown in Table III. The influent $\mathrm{BOD}_{5}$ and COD are $90 \pm 5.5 \mathrm{mg} / \mathrm{l}$ and $245 \pm 12.4 \mathrm{mg} / \mathrm{l}$ respectively. The results of the raw greywater characterization show that the $\mathrm{BOD}_{5} / \mathrm{COD}$ ratio was 0.36 , which is slightly lower than the domestic wastewater. The difference can be explained by the higher concentration of soaps and detergents in greywater, which are known to be slowly biodegradable. The average ratio of COD/TKN/T-P for greywater was estimated as 100/3.7/3, which is lower for nitrogen but higher for phosphorus compared to the domestic wastewater. So the greywater contains limited nitrogen concentration and a higher phosphorus concentration.

\begin{tabular}{cc} 
TABLE III: INFLUENT GREYWATER CHARACTERISTICS \\
\hline \hline Parameters & Greywater $\left(\mathrm{mg} \mathrm{L}^{-1}\right)$ \\
\hline $\mathrm{Ph}$ & $7.1 \pm 0.5$ \\
$\mathrm{~T}$ & $22^{{ }^{\circ}}{ }^{ \pm} 4$ \\
$\mathrm{BOD}_{5}$ & $90 \pm 5.5$ \\
$\mathrm{COD}$ & $245 \pm 12.4$ \\
Sol. COD & $177 \pm 9.5$ \\
$\mathrm{TKN}^{+}$ & $9 \pm 1.3$ \\
$\mathrm{NH}_{4}{ }^{+}$ & $1.3 \pm 0.2$ \\
$\mathrm{~T}-\mathrm{P}$ & $7.3 \pm 1.3$ \\
$\mathrm{TSS}$ & $48 \pm 8$ \\
VSS & $39 \pm 4$ \\
Grease & $<2$ \\
TDS & $301 \pm 26$ \\
\hline \hline
\end{tabular}

\section{RESUlTS AND DisCUSSION}

\section{A. MBR Model Operation}

After the MBR model calibration, the normal operational period was 50 days of operation. A comparative study between the results of the model and experimental pilot plant was done to validate the model results. Table IV shows the summary of the results of the greywater treated effluent was shown in Table III for both the MBR model and MBR pilot plant. Fig. 5-7 show the relation between effluent $\mathrm{BOD}_{5}$, COD, TKN with timerespectively, for both MBR model and MBR pilot plant. The $\mathrm{BOD}_{5}$ and COD removal efficiency for the MBR model was $96 \%$ and $96 \%$ respectively. Whereas, the removal efficiency of total nitrogen TKN and ammonia nitrogen $\mathrm{NH}_{4}$ for the MBR model were $96 \%$ and $92 \%$ respectively. Also, the total suspended solid TSS removal efficiency was more than $99 \%$.

The results of the model showed that the treated effluent of greywater has complied with international reuse criteria for different purposes. Fig. 5 and 6 showed an increase of effluent organic matter in the first 3 days of operation due to the start-up period of the MBR plant. After that, due to steady-state operation, the effluent organic matter was decreased again up to a certain limit. Fig. 7 shows the effluent total nitrogen TKN was increased during the start-up period. Although, the results showed that complete nitrification and denitrification were not achieved by the MBR plant but the effluent quality of greywater was found to be satisfactory with the all household usages purposes and toilet flushing that not need potable water quality. Table IV shows a comparison between the effluent characteristics for both the MBR model and experimental data.

TABLE IV: EFFLUENT CHARACTERISTICS FOR MBR SYSTEMS

\begin{tabular}{cccccc}
\hline \hline Parameters & $\begin{array}{c}\text { Raw } \\
\text { Greywater } \\
\left(\mathrm{mg} \mathrm{L}^{-1}\right)\end{array}$ & \multicolumn{2}{c}{$\begin{array}{c}\text { Effluent } \\
\left(\mathrm{mg} \mathrm{L}^{-1}\right)\end{array}$} & \multicolumn{2}{c}{$\begin{array}{c}\text { Removal eff } \\
. \%\end{array}$} \\
\cline { 3 - 6 } & & $\begin{array}{c}\text { MBR } \\
\text { Model }\end{array}$ & $\begin{array}{c}\text { MBR } \\
\text { plant }\end{array}$ & $\begin{array}{c}\text { MBR } \\
\text { Model }\end{array}$ & $\begin{array}{c}\text { MBR } \\
\text { plant }\end{array}$ \\
\hline BOD $_{5}$ & $90 \pm 5.5$ & $3.8 \pm 0.2$ & $4.5 \pm 0.3$ & $95.8 \pm 0.2$ & $95.0 \pm 0.3$ \\
Total COD & $245 \pm 12.4$ & $10.5 \pm 0.9$ & $13 \pm 1.2$ & $95.7 \pm 0.4$ & $94.7 \pm 0.5$ \\
$\mathrm{TKN}$ & $9 \pm 1.3$ & $0.4 \pm 0.1$ & $0.55 \pm 0.14$ & $95.6 \pm 1.1$ & $93.9 \pm 1.6$ \\
$\mathrm{NH}_{4}{ }^{+}$ & $1.3 \pm 0.2$ & $0.1 \pm 0.03$ & $0.23 \pm 0,04$ & $93.3 \pm 2.3$ & $82.3 \pm 3.1$ \\
$\mathrm{TSS}$ & $48 \pm 8$ & $0.2 \pm 0.03$ & $2.0 \pm 0.5$ & $99.6 \pm 0.1$ & $95.8 \pm 1.0$ \\
\hline \hline
\end{tabular}

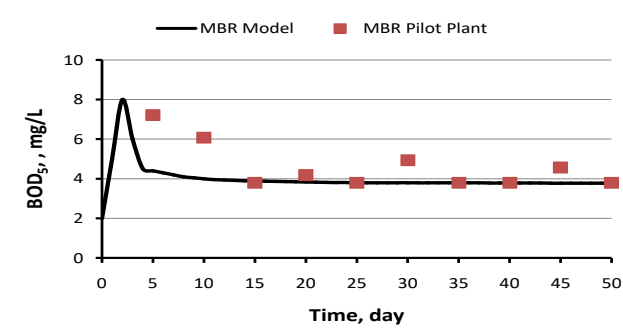

Fig. 5. Relation between effluent BOD5 with time for the MBR system.

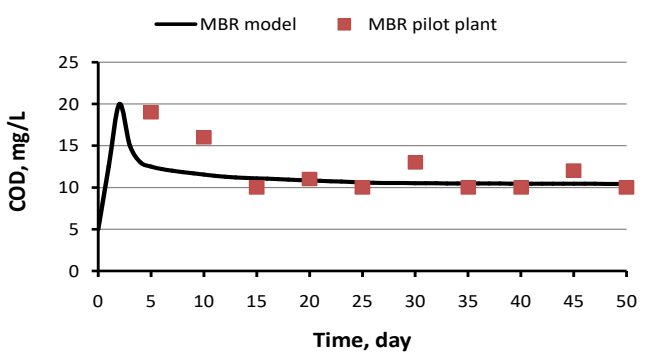

Fig. 6. Relation between effluent COD with time for the MBR system. 


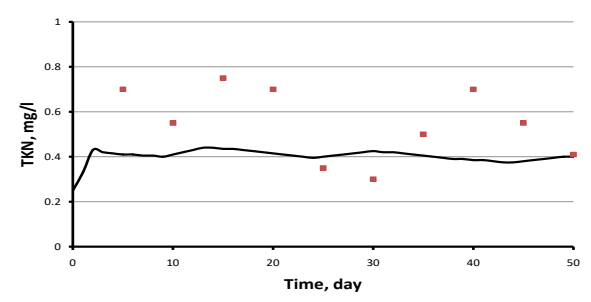

Fig. 7. Relation between effluent TKN with time for the MBR system.

\section{B. RBC Model Operation}

Table $\mathrm{V}$ shows the results of the RBC model and RBC pilot plant. The $\mathrm{BOD}_{5}$ and $\mathrm{COD}$ removal efficiency for the rotating biological contactors model was $95.5 \pm 0.3 \%$ and $92.6 \pm 0.4 \%$ respectively. Whereas, the $\mathrm{BOD}_{5}$ and $\mathrm{COD}$ removal efficiency for the RBC pilot plant were $94.7 \pm 0.4 \%$ and $92.3 \pm 1.1 \%$ respectively. Also, the removal efficiency of total nitrogen TKN and ammonia nitrogen $\mathrm{NH}_{4}$ for the $\mathrm{RBC}$ model were $65.2 \pm 6.7 \%$ and $70.8 \pm 3.8 \%$ respectively. Whereas, the TKN and $\mathrm{NH}_{4}$ removal efficiency for the RBC pilot plant were $71.1 \pm 5.6 \%$ and $78.5 \pm 5.4 \%$ respectively. Also, the removal efficiency for the total suspended solid TSS for the RBC model and RBC pilot plant was $92.8 \pm 0.6 \%$ and $86.1 \pm 0.8 \%$ respectively. Fig. 8 shows the relation between effluent $\mathrm{BOD}_{5}$ with time, Fig. 9 shows the relation between effluent COD with time, Fig. 10 shows the relation between effluent TKN with time, for both RBC model and RBC pilot plant.

TABLE V: EFFLUENT CHARACTERISTICS FOR RBC SYSTEM

\begin{tabular}{|c|c|c|c|c|c|}
\hline \multirow[b]{2}{*}{ Parameters } & \multirow[b]{2}{*}{$\begin{array}{c}\text { Raw } \\
\text { Greywater }\end{array}$} & \multicolumn{2}{|c|}{ Effluent } & \multicolumn{2}{|c|}{ Removal eff. $\%$} \\
\hline & & $\begin{array}{l}\text { RBC } \\
\text { Model }\end{array}$ & $\begin{array}{l}\text { RBC } \\
\text { Pilot } \\
\text { plant }\end{array}$ & $\begin{array}{l}\text { RBC } \\
\text { Model }\end{array}$ & $\begin{array}{l}\text { RBC } \\
\text { Pilot } \\
\text { plant }\end{array}$ \\
\hline $\mathrm{BOD}_{5}$ & $90 \pm 5.5$ & $4.05 \pm 0.3$ & $4.77 \pm 0.4$ & $95.5 \pm 0.3$ & $94.7 \pm 0.4$ \\
\hline Total COD & $245 \pm 12.4$ & $18.1 \pm 1.1$ & $18.8 \pm 1.0$ & $92.6 \pm 0.4$ & $92.3 \pm 1.1$ \\
\hline TKN & $9 \pm 1.3$ & $3.13 \pm 0.6$ & $2.6 \pm 0.5$ & $65.2 \pm 6.7$ & $71.1 \pm 5.6$ \\
\hline $\mathrm{NH}_{4}^{+}$ & $1.3 \pm 0.2$ & $\begin{array}{c}0.38 \pm 0.0 \\
5\end{array}$ & $\begin{array}{c}0.28 \pm 0.0 \\
7\end{array}$ & $70.8 \pm 3.8$ & $78.5 \pm 5.4$ \\
\hline TSS & $48 \pm 8$ & $3.46 \pm 0.3$ & $6.67 \pm 0.4$ & $92.8 \pm 0.6$ & $86.1 \pm 0.8$ \\
\hline
\end{tabular}

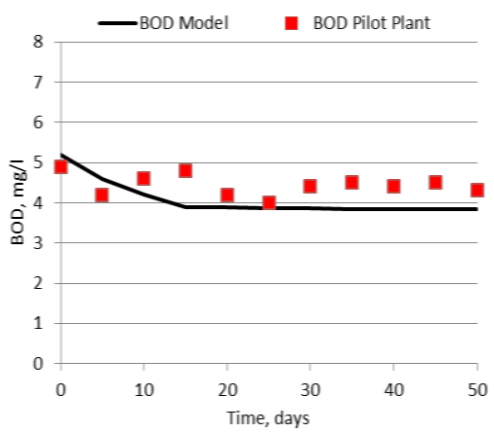

Fig. 8. Relation between effluent $\mathrm{BOD}_{5}$ with time for the RBC system.

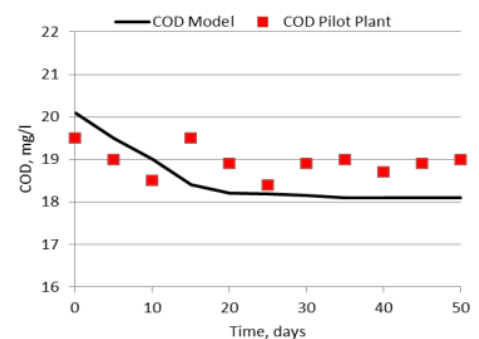

Fig. 9. Relation between effluent COD with time for the RBC system.

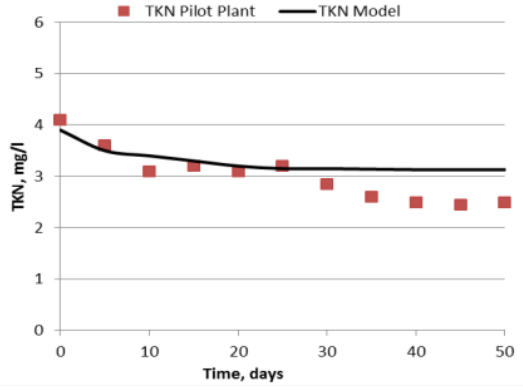

Fig. 10. Relation between effluent TKN with time for the RBC system.

\section{CONCLUSION}

Conclusions can be summarized as follows:

- Results of the simulated models and the experimental data for Both MBR and RBC systems generally exhibit good agreement between them.

- The treatment efficiency for both MBR and RBC systems based on BOD removal is ranged from 95.0 to $96.0 \%$.

- The TKN removal for the RBC system is ranged between about $65.0 \%$ to $71.0 \%$. Whereas, The TKN removal for the MBR system is ranged between about $92.0 \%$ to $95.0 \%$.

- The MBR system provides complete nitrification and suspended solid removal. Whereas, the RBC system provides less nitrification process and suspended solid removal.

- Sand filtration treatment unit before the disinfection process for the RBC unit is might be recommended to comply with water reuse criteria which also guarantee the efficiency of the disinfection unit.

- The results for both MBR and RBC units indicated that greywater could be treated and reused at many purposes after proper disinfection.

- The advantages for the RBC unit for greywater treatment in terms of operational cost, low technical experience for operational ease the MBR system.

\section{CONFLICT OF INTEREST}

The author declares no conflict of interest.

\section{REFERENCES}

[1] M. A. Amr "Studying the efficiency of greywater treatment by using rotating biological contactors system," Journal of King Saud University - Engineering Sciences, 2013.

[2] E. Friedler, Z. Shwartzman, and A. Ostfeld, "Assessment of the reliability of an on-site MBR system for greywater treatment and the associated aesthetic and health risks," Wat. Sci. \& Tech., vol. 57, no. 7, pp. 1103-1110, 2008.

[3] Y. Alfiya, A. Gross, M. Sklarz, and E. Friedler, "Reliability of on-site greywater treatment systems in Mediterranean and arid environments - A case study," Water Science \&Technology, 2013.

[4] S. Sirjit et al., "Greywater treatment and its application in cultivation of plants," Asian Journal of Microbiology, Biotechnology and Environmental Sciences, vol. 18, no. 4, pp. 1043-1053, 2016.

[5] L. Sidek, H. A. Mohiyaden, L. K. Lee, and K.Y. Foo, "Potential of engineered biomedia for the innovative purification of contaminated river water," Desalination and Water Treatment, 2016.

[6] A. Baban et al., "Greywater treatment and reuse by using RBC: A kinetic approach," Desalination and Water Treatment, 2010.

[7] P. Andrea, M. Giannotti, E. Allegrini, and T. Marras, "Integrated System of Phytodepuration for agroindustrial wastewater: Three 
different case studies," International Journal of Phytoremediation, 2015.

[8] A. K. Vuppaladadiyam et al., "A review on greywater reuse: Quality, risks, barriers and global scenarios," Rev Environ Sci Biotechnol, vol. 18, pp. 77-99, 2019.

[9] D. R. Samayamanthula, C. Sabarathinam, and H. Bhandary, "Treatment and efective utilization of greywater," Appl. Water Sci., vol. 9, no. 90, 2019.

[10] E. Atasoy, S. Murat, A. Baban, and M. Tiris, "Membrane bioreactor (MBR) treatment of segregated household wastewater for reuse," Clean, vol. 35, no. 5, pp. 465-472, 2007.

[11] H. D. Hamaiedeh, "The impact of greywater reuse in irrigation on public health and safety," Electronic Journal of Geot, Eng., vol. 15(K), pp. 1131-1138, 2010.

[12] A. Dixon, D. Butler, A. Fewkes, and M. Robinson "Measurement and modeling of quality changes in stored untreated greywater," Urban Water, vol. 1, no. 4, pp. 293-306, 2000.
Copyright ( $\odot 2021$ by the authors. This is an open access article distributed under the Creative Commons Attribution License which permits unrestricted use, distribution, and reproduction in any medium, provided the original work is properly cited (CC BY 4.0).

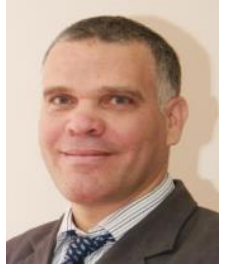

Amr M. Abdelkader was born on 14 November 1971, in Alexandria, Egypt. He got a Ph.D. degree in sanitary engineering from Alexandria University in 2004. He works as an associate professor at the University of Business and Technology, UBT University at Jeddah, Saudi Arabia. He works also as associate professor (on leave) at Sanitary Engineering Department, Faculty of Engineering, Alexandria University. 